\title{
The Social Dynamics of Illegal Wood Harvesting on Indigenous Woody Vegetation: A Case Study of Chimanimani National Park, Eastern Zimbabwe
}

\author{
Never Muboko, Langton Zengeni, Clayton Mashapa*, Gladman Chibememe, Edson Gandiwa \\ School of Wildlife, Ecology and Conservation, Chinhoyi University of Technology, Chinhoyi, Zimbabwe \\ Email: *clayiemashapa@yahoo.co.uk
}

How to cite this paper: Muboko, N., Zengeni, L., Mashapa, C., Chibememe, G., \& Gandiwa, E. (2019). The Social Dynamics of Illegal Wood Harvesting on Indigenous Woody Vegetation: A Case Study of Chimanimani National Park, Eastern Zimbabwe. Open Journal of Forestry, 9, 381-396.

https://doi.org/10.4236/ojf.2019.94021

Received: July 18, 2019

Accepted: October 22, 2019

Published: October 25, 2019

Copyright $\odot 2019$ by author(s) and Scientific Research Publishing Inc. This work is licensed under the Creative Commons Attribution International License (CC BY 4.0).

http://creativecommons.org/licenses/by/4.0/

(c) (i) Open Access

\begin{abstract}
Illegal wood harvesting, a factor that threatens conservation efforts, was assessed in Chimanimani National Park (CNP), eastern Zimbabwe, in April 2016. The study identified preferred indigenous woody species, determined the uses and quantities of indigenous wood extracted, and established local people's knowledge and perceptions on forest resource conservation, institutional framework and management by-laws. Mixed data collection methods, which included questionnaires and semi-structured interviews were used. For questionnaires, a three-stage sampling design was adopted; that is, purposive sampling, where three Wards (i.e. Chikukwa Ward 11, Chikwakwa Ward 17 and Ngorima Ward 5b) were selected as study areas from a total of seventeen Wards in Chimanimani District. The three selected Wards had a combined total of 15 villages. Stage 2 involved random sampling, where three villages, one from each selected Ward, i.e. Batanai (75 households), Chikukwa (110 households) and Tamuka (46 households), with a total of 231 households, were chosen. Stage 3 was the random selection of households, where 46 questionnaires were administered and collected in the 3 selected villages, representing $20 \%$ of the targeted population. The study results highlighted that the preferred woody species included those of Acacia, Bauhinia, Brachystegia, Combretum, Pericopsis and Terminalia genera. The illegally harvested indigenous woody plants were principally for household uses. Quantities collected ranged from 0.2 to 0.4 tons for firewood monthly and 3 to 6 tons mostly for tobacco curing. Most respondents reported that by-laws were not effective in combating illegal wood harvesting. It was concluded that CNP woodlands are under pressure due to illegal wood harvesting. It is recom-
\end{abstract}


mended that a robust community-based strategy to conserve woody species and natural resource utilisation be developed.

\section{Keywords}

Biodiversity Conservation, Illegal Wood Harvesting, Perceptions, Preferred Woody Species, Social Dynamics

\section{Introduction}

Disturbances taking place in protected areas, especially on indigenous woody species posed by human activities are a cause for concern. Overexploitation of indigenous woody species is becoming an acute ecological tragedy of modern times as there is an increasing trend, fueled by high demand for timber, agriculture, mining and energy (Stuat \& Adams, 1990; Tsai et al., 2019). Comiskey et al. (2003) argued that nearly half of the protected forests in the world ranging between 750 and 800 million hectares of the original 1.5 to 1.6 billion hectares that previously decorated the planet were cleared.

In Asia, some protected areas like Malaysia's Janda Baik face massive pressures of deforestation ${ }^{1}$ due to human encroachment, increased demand for forest products, urban development and illegal agricultural practices (World Wide Fund, WWF, 2001). In South America, Brazil's commercial farmers clear cerrado and engage in illegal wood harvesting in protected forests to generate large profits with an estimated 8.5 million hectares of protected tropical rainforests in Brazil being lost every year (Thomas, 2004). The rate and profitability of deforestation is also influenced by changes in agricultural prices (Dallmeier, 1992). Hence, the protected tropical rainforests of Brazil were estimated to be less by $90 \%-95 \%$ of their original state in the early 2000s (WWF, 2001).

On the African continent, loss of vegetation in protected areas was estimated to be accounting for around 55\% of global forest loss (WWF, 2001). Counsell (2009) projected that according to the United Nations' Food and Agriculture Organization (FAO), Africa's forests covering about 630 million square kilometers declined by an average rate of $0.6 \%$ year on year from 1990 to 2005 . A study in Kibali National Park, Uganda by Mackenzie et al. (2011) observed that deforestation due to increased need for natural forest resources was prevalent. Tanzania lost over 400,000 hectares of forest between 2000 and 2005 due to high demand for forest products (FAO, 2007). Other African countries with documented high levels of illegal wood harvesting include the Congos, Ethiopia, Ghana, Kenya and Nigeria (Mugabe \& Clark, 1998). In Kenya, for example, Masaai communities engaged in charcoal burning as an economic alternative to their declining pastoral lifestyle as well as the use of woody species like Acacia

${ }^{1}$ Deforestation-the process whereby vegetation is removed for various purposes resulting in the part of the land partially or completely exposed to negative element (Penny, 2009). 
species (Acacia senegalenses, Acacia tortilis, Acacia mellifera, Acacia xanthophloea, Acacia nilotica, Acacia mellifera and Balanites glabra) for various uses like fencing and construction (International Centre for Research in Agro-forestry, ICRAF, 1992; Herlocker, 1999; Kilinge \& Okello, 2005). In southern Africa, forests and woodlands are the primary energy sources in the form of wood fuel or charcoal and a source of commercial timber, with hard-wood species such as Pterocarpus angolensis (kiaat), Afzelia quanzensis (chamfuta), Dalbergia melanoxylon (African blackwood), Combretum imberbe (leadwood), Diospyros mespiliformis (African ebony), Pericopsis elata (African teak) and Khaya anthotheca (red mahogany) being selectively targeted (McCullum, 2000). These important woody species are now mainly confined to protected areas (e.g. Gandiwa, 2011; Lui \& Coomes, 2016; Tsai et al., 2019).

Looking back, it was noted that during the pre-colonial and early colonial periods of the 19th century, illegal wood harvesting was minimal in Africa due to low human populations and demand (Mamimine \& Mandiregerei, 2001). However, from the 1890s onwards, extensive exploitation of timber from indigenous woodlands began in Zimbabwe to supply developments such as mining and railways infrastructure for the pioneer column during the advent of the colonial period. This exploitation became so extensive that regulation became necessary, leading to the enactment of the Forest Act of 1949 (McGregor, 1991). Despite the unavailability of adequate data, indications are that by 1977 timber demand had already exceeded supply in Zimbabwe, hence fueling over-exploitation of woodlands (Shumba, 2001). The aim of the then Rhodesia (now Zimbabwe) Forestry Act of 1949 was to ensure that indigenous forests continued to provide timber for railway sleepers, mining and high-quality flooring for which they were being logged since the turn of the twentieth century (McGregor, 1991; Shumba, 2001). This Forestry Act of 1949 was later superseded by the Zimbabwe Forest Act (Chapter 19.05) as amended in 1999.

Despite the presence of legislative frameworks on forestry in Zimbabwe, FAO (2007) and Forest Commission of Zimbabwe (2012) stated that an average of 327,000 hectares or $1.48 \%$ of forest cover per year were lost between 1990 and 2010. Indigenous woody species notably of Acacia, Brachystegia genera and Julbernardia globiflora were reportedly targeted by local communities, threatening woodland conservation efforts and stands out as one of the greatest challenges facing local and national authorities throughout Zimbabwe, as communities depend on woody vegetation as a source of fuel energy (Nduku, 1993; Clarke, 1994; Chenje \& Paleczny, 1998; Cunningham \& Saigo, 1999; Muboko et al., 2014). Based at the high rates of deforestation, it is projected that a few of Zimbabwe's protected natural forests will survive to the end of the $21^{\text {st }}$ century in their current pristine state.

In Chimanimani National Park (CNP), there are concerns over woodland degradation from anthropogenic activities (Gandiwa \& Gandiwa, 2012). This study therefore aimed to address the following objectives, i.e. to: 1) identify preferred 
indigenous woody species, determine the uses and quantities of indigenous woody plants extracted by communities adjacent to the CNP, and 2) assess the local knowledge and perspectives on the effectiveness of forest resource by-laws ${ }^{2}$ and the institutional frameworks in forest resource management.

\section{Materials and Methods}

\subsection{Study Area}

CNP was designated as a protected area in 1985 , covers $171 \mathrm{~km}^{2}$ and is located in the eastern highlands of Zimbabwe (Figure 1). CNP is situated in a wet agro-ecological zone, with an altitude of over $1500 \mathrm{~m}$ above sea level. Mean annual rainfall varies between 1500 and $2000 \mathrm{~mm}$, with a mean annual temperature variation of $22^{\circ} \mathrm{C}$ in the south east lowlands to less than $18^{\circ} \mathrm{C}$ at the peak of the Chimanimani mountains (Moyo et al., 1993). CNP is bound on the eastern side by the Chimanimani mountain range which runs southwards parallel to the Zimbabwe and Mozambique international boundary. At the time of the study,

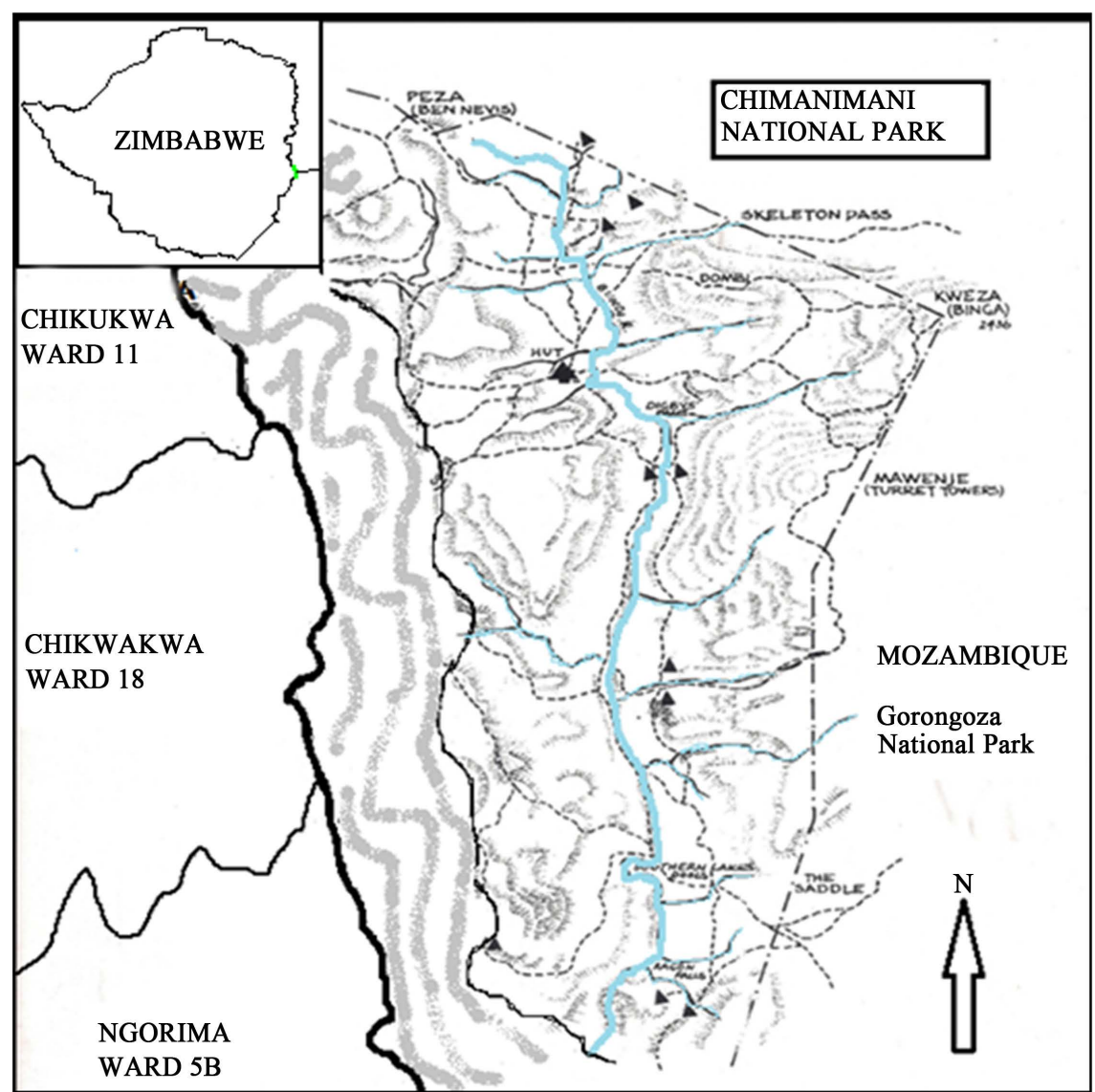

Figure 1. Location of Chimanimani National Park and the surrounding communal settlements eastern Zimbabwe.

${ }^{2}$ By-laws-refer to a law of local or limited application passed under the authority of a higher law specifying what things may be regulated by the by-law. They are subsidiary laws that are enacted by the local governments (Nkonya et al., 2005). Forest resource management by-laws complement national and international laws. 
there was an average human population density of about 33 persons per $\mathrm{km}^{2}$ with an annual average growth rate of $1.1 \%$ over the period 2002 to 2012 across the communal settlement areas bordering CNP, namely; Ngorima Ward 5b (13,375 ha), Chikukwa Ward 11 (10,225 ha) and Chikwakwa Ward 17 (6375 ha) (ZimStats, 2013).

\subsection{Data Collection}

A mixed methods approach was used, relying mainly on household questionnaires and semi-structured interviews with key informants conducted over the month of April 2016. For the household questionnaire, a three-stage sampling design was adopted; that is, 1) purposive sampling, where three Wards (Chikukwa Ward 11, Chikwakwa Ward 17 and Ngorima Ward 5b) were selected as study areas from a total of seventeen Wards in Chimanimani District, 2) random sampling, where three villages were selected, i.e. Batanai (75 households) in Chikwakwa Ward 17; Chikukwa (110 households) in Chikukwa Ward 11, and Tamuka (46 households) in Ngorima Ward 5b and totalling 231 households. At the time of the study, the 3 Wards had a total of 15 villages. The third stage was the random selection of households where 46 questionnaires were administered and collected in the 3 selected villages, representing $20 \%$ of the targeted population. The smallest developmental unit of human settlement in rural Zimbabwe is the village, comprising an average of approximately 35 households, whereas, Wards group together six to twelve villages (Madzudzo, 1997; Mashapa et al., 2019). Guided by the study objectives, the household questionnaire sought respondents to identify the most preferred harvested woody species, their uses and associated challenges in forest resource management, the quantities of woody plants they extract from the study area and their perceptions on institutional and legal frameworks on local forest resource management. In addition, semi-structured interview guides were used on 12 key informants selected through convenience sampling and these key informants included officials from government parastatals (Environmental Management Agency, Zimbabwe Parks and Wildlife Management Authority (ZPWMA), Forestry Commission, Department of Agriculture [Agritex]), Chimanimani Rural District Council, Traditional leaders (village heads), Councilors and a private company (Border Timbers), all from Chimanimani District, Zimbabwe.

The key informant interview guide included questions on policy implications on protected area management and how government departments were enforcing by-laws of woodland management across the study area. Key informants were also asked to highlight the impact of human activities on the woody vegetation of the study area. Seventy-six percent $(76 \%, n=35)$ of the household study respondents' ages ranged from 35 to 60 years and about $11 \%(n=5)$ were over 60 years old. However, $13 \%(n=6)$ of the respondents were less than 30 years old. Literacy was high as most respondents reported being educated with $71 \%$ ( $n$ =33) of the household heads having received at least primary education. About 
$85 \%(n=39)$ of the household study respondents were not formally employed and were involved in smallholder rain-fed agriculture.

\subsection{Data Analysis}

Descriptive statistics (e.g. mean and variances) were used to describe and compare recorded variables across the sampled areas and to analyze the local perceptions on the effectiveness of natural forest resource by-laws in the study area in Chimanimani, Zimbabwe. Statistical tests including the chi-square test were employed to determine whether there were differences on gender composition, indigenous woody species preferences and woody resource uses, quantity ranges of wood collected and perceptions on woodland management by-law effectiveness in different villages in the selected Wards. Study results were presented in figures and descriptive narrations. All analyses were done using the Statistical Package for Social Sciences (SPSS) version 16.0 (SPSS Inc., Chicago, USA).

\section{Results}

\subsection{Preferred Indigenous Woody Species, Uses and Quantities Extracted by Communities Adjacent to the CNP}

\subsubsection{Preferred Indigenous Woody Species}

The indigenous woody species preferences per village were as follows; Acacia (20\%) and Combretum (14\%) for Tamuka in Ngorima Ward 5b, Bauhinia (18\%) and Terminalia (13\%) for Chikukwa in Chikukwa Ward 11 and Pericopsis (19\%), Brachystegia (13\%) and Combretum (13\%) for Batanai in Chikwakwa Ward 17. Almost half of the respondents, about $48 \%(n=22)$ preferred to use two or more indigenous woody species (Acacia, Bauhinia, Brachystegia, Combretum, Pericopsis and Terminalia), while about $11 \%(n=5)$ preferred Combretum and Pericopsis, 8\% $(n=4)$ preferred Bauhinia and Acacia, and 6.5\% preferred Terminalia and Brachystegia (Figure 2(a)).

Preferred indigenous woody species did not differ $\left(\chi^{2}=2.34, \mathrm{df}=14, p>0.05\right)$ across the study villages.

\subsubsection{Uses and Quantities of Harvested Indigenous Woody Plants}

The quantities of indigenous woody vegetation collected varied with the purposes, some of which overlapped. The four main purposes identified were for firewood, construction material, fencing and tobacco curing. Over sixty percent $(60.9 \%, n=28)$ of respondents used wood for household chores like firewood, fencing and building, while 13\% $(n=6)$ reported using woody plants/products for two or more different purposes such as for agriculture, carpentry and carving. Few $(11 \%, n=5)$ reported that they are engaged in commercial carpentry and carving. There was a significant difference $\left(\chi^{2}=95.49, \mathrm{df}=14, p<0.001\right)$ in indigenous woody species use across the study villages.

For firewood, most household respondents in all sampled villages collected between 0.2 to 0.4 tons of firewood per month, with $43.8 \%$ in Ward $11,40 \%$ in 
N. Muboko et al.

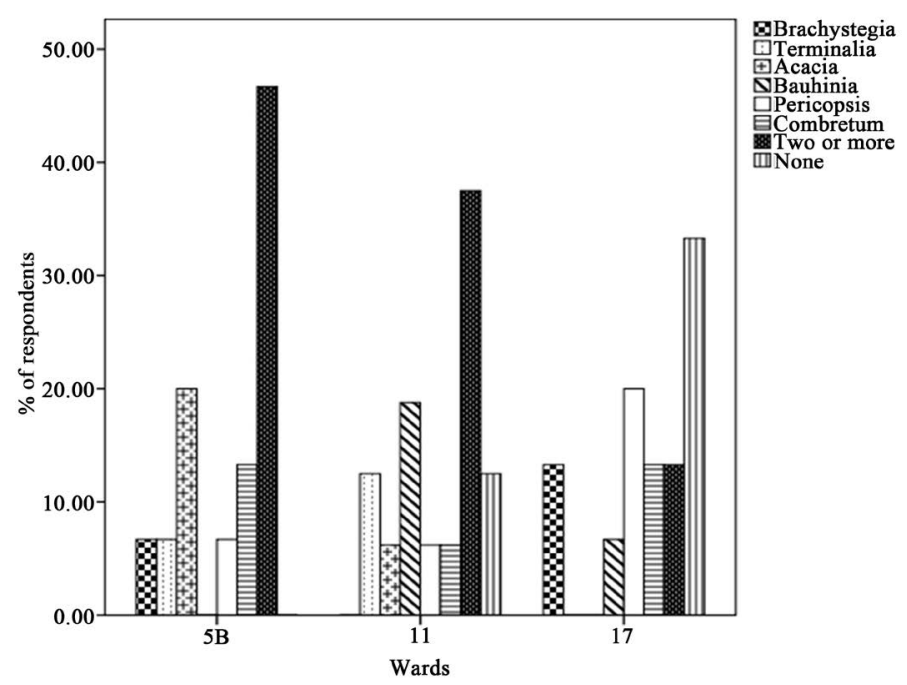

(a)

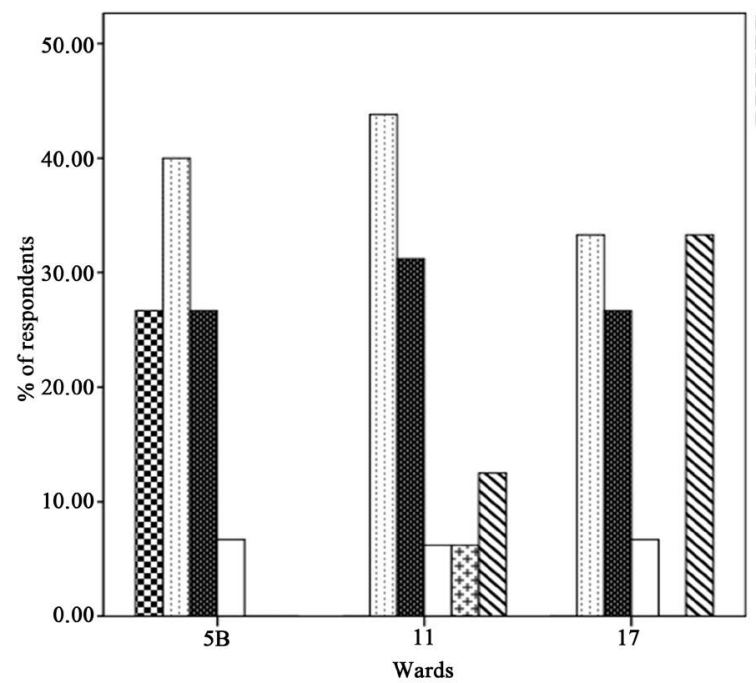

(b)

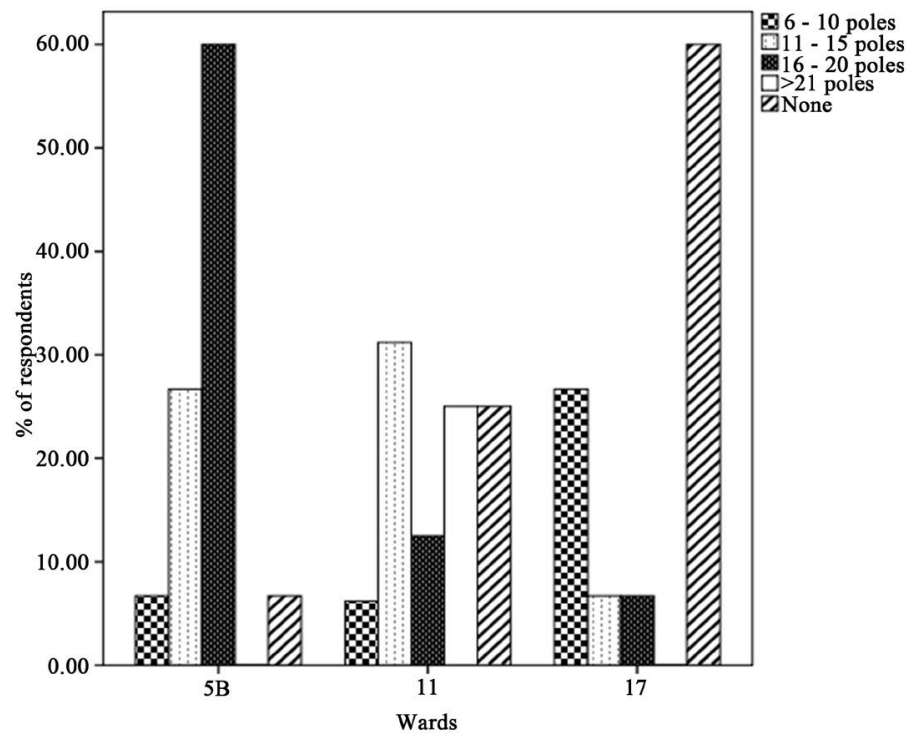

(c) 


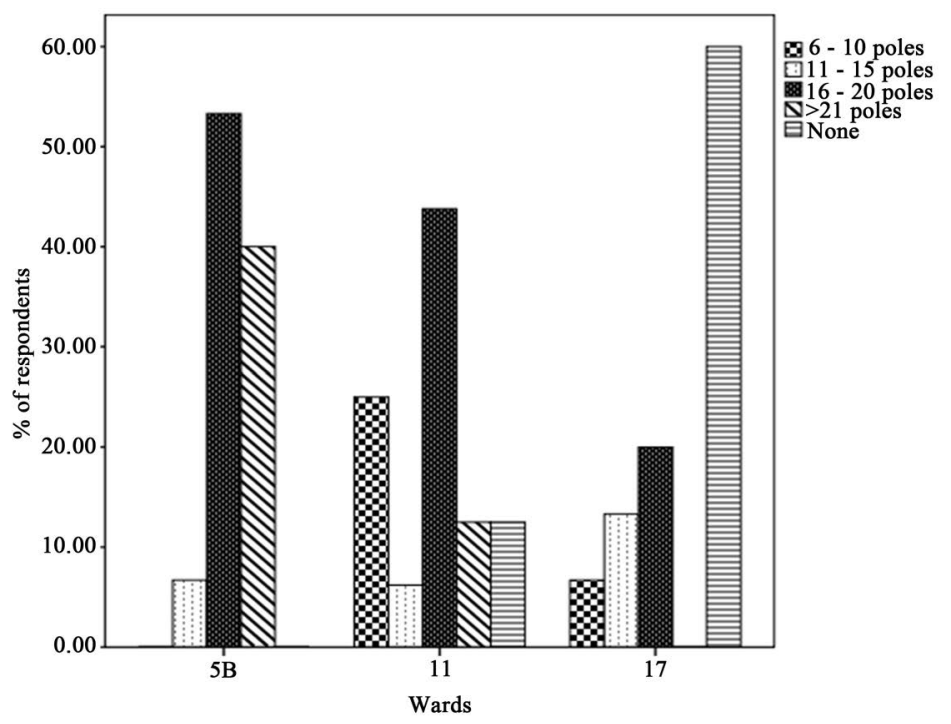

(d)

Figure 2. (a)-(d) Indigenous woody vegetation harvested for varied purposes from Chimanimani National Park, eastern Zimbabwe. Notes: The percentage of respondents indicate responses from the selected villages in the following; Wards $5 \mathrm{~B}=$ Ngorima Ward $5 \mathrm{~b}$, 11 = Chikukwa Ward 11 and 17 = Chikwakwa Ward 17. (a) Preferred indigenous woody species per Ward's village; (b) Quantity of woody plants collected for firewood per month per Ward's village; (c) Quantities of woody plants collected for construction per month per village; (d) Quantity of woody plants collected as fencing timber per month per village.

Ward 5b, and 33.3\% in Chikwakwa Ward 17, while $28.3 \%$ collected between 0.4 to 0.6 tons, $8.7 \%$ collected $<0.2$ tons, $6.5 \%$ collected between 0.6 to 0.8 tons and the least $(2.2 \%)$ collected $>0.8 \mathrm{t}$ of firewood per month. About $15 \%$ of respondents did not collect woody plants for firewood in CNP. Overall, about $48 \%$ of respondents collected timber monthly, $34.8 \%$ weekly and a few $(2.2 \%)$ collected firewood in the CNP when needed (Figure 2(b)). However, 15.2\% reported that they had no time to collect firewood in the park. There was a significant difference $\left(\chi^{2}=57.97 ; \mathrm{df}=15 ; p<0.001\right)$ between the quantity of firewood collected and frequency of collection across the study area.

Indigenous woody plants were also collected for use as construction timber. Most respondents (26.1\%) collected 16 - 20 wood poles, a few $(21.7 \%)$ collected 11 - 15 poles, $13 \%$ collected $6-10$ poles and the least (8.7\%) collected more than 21 poles (Figure $2(\mathrm{c})$ ). Respondents who did not collect timber for construction constituted the highest percentage $(60 \%)$ in Chikwakwa Ward 17. In contrast most respondents (60\%) in Ngorima Ward 5b collected $16-20$ poles and a few (31.2\%) in the village in Chikukwa Ward 11 collected $11-15$ poles. The quantity of timber collected for construction purposes differed significantly $\left(\chi^{2}=30.23\right.$, df $=8, p<0.001)$ across the study villages.

Results for indigenous woody plants collected for use as fencing timber indicated that most respondents (39.1\%) collected between 16 - 20 wood poles, $17.4 \%$ collected more than 21 poles, $10.9 \%$ collected 6 - 10 poles and a few $(8.7 \%)$ col- 
lected 11 - 15 poles per month (Figure 2(d)). About 23. 9\% did not collect woody vegetation for fencing poles. There was a significant difference $\left(\chi^{2}=58.97, \mathrm{df}\right.$ $=12, p<0.001$ ) between the quantity of fencing timber collected per month and frequency of collection across the Wards' study villages.

For tobacco curing, about $11 \%(n=5)$ of respondents collected 3 to 6 tons and just $2.2 \%$ collected 1.5 to 3 tons of fuelwood. The quantity of wood collected for tobacco curing did not differ significantly $\left(\chi^{2}=2.37, \mathrm{df}=4, p>0.05\right)$ across Wards' selected villages. However, most respondents $(87 \%, n=40)$ did not use indigenous woody plants for tobacco curing and $85 \%(n=39)$ respondents did not collect wood from CNP for that cause.

\subsection{Local Knowledge and Perspectives on the Effectiveness of Forest Resource By-Laws and the Institutional Frameworks in Forest Resource Management}

All key informants from Zimbabwe's government ministries, Chimanimani Rural District Council (CRDC), traditional leaders and councilors $(n=12)$ had some knowledge of various laws and policy frameworks that could be used to help control the indiscriminate forest resource utilization in CNP. These laws and policies included the Environmental Management Act (Chapter 20: 27) of 2002, the Communal Land Forest Produce Act (Chapter 19: 04) of 2001, the Traditional Leaders' Act (Chapter 29: 17) of 2001, the Forest Based Land Reform Policy and the Wildlife Based Land Reform Policy of 2006. Key informants from the traditional leadership and councilors reported that their main role was of educating villagers in natural resources management including forest resources, formulating and enforcing natural resources rules and regulations and preventing people from the indiscriminate cutting down of plants. They reported that they were just doing it with less assistance from other key government institutions like EMA, CRDC, ZPWMA and Forest Commission of Zimbabwe as officials from such agencies are based outside the villages and were normally not visible as they did not undertake regular monitoring and inspections in and around the CNP. Key informants from EMA, Agritex, Forestry Commission of Zimbabwe, CRDC and ZPWMA stated that their organizations were key institutions in forest resource management in Chimanimani District. However, they agreed in principle that collaborating with the local communities to promote conservation was key.

From the household respondents, 97.8\% $(n=45)$ confirmed that the forest resource management institutions were present and $2.2 \%(n=1)$ reported that they were not aware of any forest resource management institutions. There was a significant difference $\left(\chi^{2}=46.00, \mathrm{df}=4, p<0.001\right)$ in responses to the presence and awareness on the roles of forest resource management institutions. Fewer respondents $(30.4 \%, n=14)$ reported awareness of the roles of government parastatals such as EMA, ZPWMA and Forest Commission of Zimbabwe, whereas $13.3 \%(n=6)$ noted the role of Traditional leaders and Chimanimani Rural Dis- 
trict Council as custodians of woodlands and its resources.

Most of the household respondents $(95.7 \%, n=44)$ reported that forest resource management by-laws were present and a few $(4.3 \%, n=2)$ reported that they were not aware of any forest resource management by-laws. There was a significant difference $\left(\chi^{2}=26.76, \mathrm{df}=4, p<0.001\right)$ between the awareness of the presence of forest resource by-laws and by-laws in place. The respondents reported different by-laws that were in place for forest resource management like conservation of woody vegetation under both communal and protected area management. About 35\% $(n=16)$ of the respondents stated the conservation of natural resources as the key regulatory requirement they know, 32.6\% $(n=15)$ stated "avoidance of" deforestation, $17.4 \%(n=8)$ mentioned "avoidance of" wildfires and a few $(10.9 \%, n=5)$ reported "avoidance of" siltation as strategies to conserve forest resources. In contrast $4.3 \%(n=2)$ reported they were not aware of any by-laws in place for natural resource management. However, there were no significant differences in responses to forest resource management by-laws that respondents are aware of $\left(\chi^{2}=13.245, \mathrm{df}=8, p>0.05\right)$ across the Wards'study villages.

Most of the respondents $(54.3 \%, n=25)$ reported that forest resource management by-laws were not effective at all, while $39.1 \%(n=18)$ said they were effective and $2.2 \%(n=1)$ reported that they were very effective. However, $4.3 \%$ ( $n$ $=2$ ) of study respondents opted not to comment on the effectiveness of the rules and regulations of forest resource management. There was a significant difference $\left(\chi^{2}=54.94, \mathrm{df}=12, p<0.001\right)$ between awareness of the existing by-laws and their perceived effectiveness across the sampled Wards' study villages.

\section{Discussion}

Different indigenous woody species have different uses depending on the preference of the users. The study highlighted that most respondents preferred to use two or more of the indigenous woody species from CNP, namely; Acacia, Bauhinia, Brachystegia, Combretum, Pericopsis and Terminalia genera. The study findings indicated that woody species extracted from the protected CNP were selected based on genotype. The selective extraction of woody species tends to reduce the abundances of hardwood species leaving the softwood types. Elsewhere in Mukuvisi Woodlands, Harare, Zimbabwe, selective logging through illegal wood harvesting led to degradation of the Miombo woodlands as evidenced by the decline in the preferred woody genera such as the Julbernardia and Brachystegia (Muboko et al., 2014). In the Chipinge District, Zimbabwe, in an area located nearby and to the west of the present study area, the pepper-bark tree (Warburgia salutaris), which is well known for its medicinal properties, was reported near extirpation because of over harvesting (Mashapa et al., 2019). Bivinia jalbertii (Cobweb seed), a species which yields durable wood poles that can last for many years, and is endemic to the Nyoni Hills near Ngundu, Zimbabwe is also under threat (Mashapa, 2018). However, in some cases respondents indi- 
cated, for example in Ngorima Ward 5b, that they engage in non-selective use of indigenous woody species.

As commonly reported from sub-Sahara African studies, the extracted indigenous woody plants from CNP were reported principally for household uses, such as firewood, building and fencing, followed by other purposes like for agriculture, carpentry and carving (Kusimi, 2015; Sloan \& Sayer, 2015; Tsai et al., 2019). This is consistent with other studies carried out elsewhere, for instance, Mugabe \& Clark (1998) observed that the Maasai in Kenya extracted woody vegetation in Amboseli National Park for household needs. Other factors like the rapid population growth in Zimbabwe (ZimStats, 2013) and the related urbanization are exerting pressure on habitats and ecosystems surrounding towns and rural service centres through the provision of infrastructural services such as houses and industrial activities as well as domestic demand for fuel wood (Shumba, 2001; Mashapa et al., 2019). In the present study Terminalia and Combretum species were reported mainly used for fencing and Acacia used for building as evidenced by the huts made of wood poles and dagga, as well as livestock kraals made up of wood poles. This is partly consistent with ICRAF (1992) findings in Maasai of Kenya where the use of Acacia species for construction and fencing was reported.

We recorded varied quantities and frequency of collection of indigenous woody plants with use. This concurs with the findings of Acheampong et al. (2018) on community participation in forest management, the case of Sefwi-Wiawso forest district, Ghana. Firewood was mainly collected monthly and when need arose for other uses. Many respondents in the village in Chikukwa Ward 11 tend to use more woody plants for firewood than any other village in the studied Wards. With such a high level of dependence on fuelwood (Figure 2(b)) and with the increasing human population around CNP (ZimStats, 2013), this will likely create a deficit of this important woody vegetation resource. This observation supports Mutepfa et al. (1998) who stated that thirty one percent of Zimbabwe's total energy consumption is fuelwood, with eighty percent of the energy demands of communal people in rural areas being met by fuelwood. Thus, preferred woody species are likely being rapidly harvested for firewood in most rural areas of Zimbabwe. However, this may not be surprising as Cunningham \& Saigo (1999) observed that in eastern Africa, the demand for firewood is estimated to be ten times the sustainable yield.

It was recorded that forest resource management by-laws were present, and most respondents agreed that by-laws were formulated by various institutions which included EMA, Department of Agriculture, Forestry Commission of Zimbabwe, ZPWMA, RDCs and Traditional leaders. However, most of the respondents reported that the forest resource management by-laws were not effective as expected. It was revealed that contemporary forest resource management by-laws did not consider the existence of indigenous knowledge systems. This concurs with the findings of Mashapa et al. (2019) in Save Valley, southeastern 
lowveld of Zimbabwe. Locally, indigenous knowledge represents a way of life that has evolved with the local environment, so it is specifically adapted to the requirements of local conditions (Tsai et al., 2019; Acheampong et al., 2018). Key informants argued that there was less coordination between the relevant institutions responsible for forest resources and woodland management across the study area.

We however observed that most household respondents were aware of the existence of institutions that enforce conservation by-laws. Nevertheless, key informants reported the existence of resistance towards the by-laws that govern forest resource use in their areas and CNP. For example, EMA Officers for Chimanimani District were concerned that so many orders were given to perpetrators to desist from illegal activities, but these were largely ignored. In that regard, co-management of the protected woodlands involving CNP and the local people is ideal for forest resource conservation. Local people and their indigenous knowledge systems can be co-opted or integrated with conventional science to promote certain sustainable-customary uses of woody vegetation resources by the communal people living at the periphery of protected areas like the CNP. This may contribute to sustainable development and sound co-management practices, since CNP like most protected areas in southern Africa does not include a component that is strongly linked to communal areas (Murphree, 1993; Murphree, 2005). However, South Africa is a good case study of state protected areas interlinked to community-based natural resource management initiatives with a focus on co-management, benefit sharing, and innovations such as "contractual parks" (Reid \& Turner, 2004). Management of contractual parks is carried out in accordance with a joint management agreement devised by a board comprising representatives of both the local community and the national conservation authority (Reid, 2002). For instance, protected areas are known to accumulate dead wood from natural plant-diebacks and due to pest and diseases, and climatic factors like drought and frost. Thus, protected areas like CNP can consider establishing a controlled and transparent system that permits local rural people living at the periphery of the park to collect dead wood from the park.

\section{Conclusion and Recommendations}

In this study we aimed to address the following objectives, 1) to identify preferred indigenous woody species, determine the uses and quantities of indigenous woody plants extracted by communities adjacent to the CNP, and 2) assess the local knowledge and perspectives on the effectiveness of forest resource by-laws and the institutional frameworks in forest resource management. Local communities around CNP showed a high preference for selected indigenous woody species, which are illegally harvested from the Afromontane woodlands of CNP, namely; Acacia, Bauhinia, Brachystegia, Combretum, Pericopsis and Terminalia genera. The main purpose of the indigenous woody plants is for domestic uses like, fuelwood, construction, fencing and tobacco curing. Quantities 
of indigenous woody plants collected varied with the purpose or use and the village. This could be attributed to the location and access to indigenous forests. Responses on the local knowledge and perspectives on the effectiveness of forest resource by-laws and the institutional frameworks in forest resource management indicated that although most respondents expressed awareness of the laws and institutional frameworks governing forest resources, illegal wood harvesting still occurs. This could explain why varied responses were obtained on the effectiveness of the by-laws put in place to regulate and manage forest resources. To strengthen the effectiveness of forest resource by-laws and the institutional frameworks, we recommend several actions including improvements on coordination and law enforcement efforts, and the reformation of forest resource conservation legislative framework to provide incentives for local communities to cooperate in the conservation of woody species found within protected areas and adjacent areas. This can be achieved by adopting the Communal Area Management Programme for Indigenous Resources (CAMPFIRE) concept which has to a larger extent been largely successful in the wildlife sector in Zimbabwe. There is also need for the introduction of alternative sources of energy, especially renewable energy and making affordable building materials such as cement and iron sheets so that people in the low-income category can afford to use more of these building materials instead of woody vegetation resources. This is expected to curb the demand for indigenous woody plants.

\section{Acknowledgements}

We acknowledge the Zimbabwe Parks and Wildlife Management Authority for granting us permission to carry out this study in Chimanimani National Park. We are in-debted to the Parks staff based at Chimanimani National Park for their support in data collection, the Chimanimani Rural District Council and the respective traditional leaders for permitting us to conduct interviews in their communities as well as the participants who made this study possible. We also appreciate the Manicaland Provincial Office of the Environmental Management Agency and its Provincial staff for their support.

\section{Conflicts of Interest}

The authors declare no conflicts of interest regarding the publication of this paper.

\section{References}

Acheampong, E. O., Agyeman, K. O., \& Amponsah, O. (2018). The Motivation for Community Participation in Forest Management: The Case of Sefwi-Wiawso Forest District, Ghana. International Forestry Review, 20, 1-17. https://doi.org/10.1505/146554818822824264

Chenje, M. S., \& Paleczny, D. (1998). The State of Zimbabwe Environment. Harare: Ministry of Mines. Environment and Tourism.

Clarke, J. (1994). Building on Indigenous Natural Resources Management: Forestry Prac- 
tices in Zimbabwe's Communal Lands. Harare: Forestry Commission.

Comiskey, J. A., Sunderland, T. C. H., \& Sunderland-Groves, J. L. (2003). Takamanda: The Biodiversity of an African Rainforest. SI/MAB Series. Washington DC: Smithsonian Institution.

Counsell, S. (2009). Forest Governance in Africa, Occasional Paper No. 50. Governance of Africa's Resources Programme.

Cunningham, W. P., \& Saigo, B. W. (1999). Environmental Science: A Global Concern (5th ed.). Boston, MA: McGraw-Hill.

Dallmeier, F. (1992). Long-Term Monitoring of Biological Diversity in Tropical Forest Areas: Methods for the Establishment and Inventory of Permanent Plots. MAB Digest. State of the World's Forests 2007. Rome: FAO.

FAO (2007). State of the World's Forests 2007. Food and Agriculture Organization of the United Nations, Rome. http://www.fao.org/docrep/009/a0773e/a0773e00.htm

Forest Commission of Zimbabwe (2012). Forestry Information Brochure. Harare.

Gandiwa, E. (2011). Importance of Dry Savanna Woodlands in Rural Livelihoods and Wildlife Conservation in Southeastern Zimbabwe. Nature \& Faune, 26, 60-66.

Gandiwa, E., \& Gandiwa, P. (2012). Biodiversity Conservation versus Artisanal Gold Mining: A Case Study of Chimanimani National Park, Zimbabwe. Journal of Sustainable Development in Africa, 14, 29-37.

Herlocker, D. (1999). Rangeland Resources in Eastern Africa: Their Ecology and Development. Nairobi: GTZ.

ICRAF (1992). A Selection of Useful Trees and Shrubs for Kenya. Nairobi: ICRAF.

Kilinge, J. W., \& Okello, M. M. (2005). Use and Availability of Tree and Shrub Resources on Masaai Communal Rangelands near Amboseli, Kenya. African Journal of Range and Forage Science, 22, 37-46. https://doi.org/10.2989/10220110509485860

Kusimi, J. M. (2015). Characterizing Land Disturbance in Atewa Range Forest Reserve and Buffer Zone. Land Use Policy, 49, 471-482.

https://doi.org/10.1016/j.landusepol.2015.08.020

Lui G. V., \& Coomes, D. A. (2016). Tropical Nature Reserves Are Losing Their Buffer Zones, But Leakage Is Not to Blame. Environmental Resources, 147, 580-589. https://doi.org/10.1016/j.envres.2015.11.008

Mackenzie, C. A., Chapman, C. A., \& Sengupta, R. (2011). Spatial Patterns of Illegal Resource Extraction in Kibale National Park, Uganda. Environmental Conservation, 39, 38-50. https://doi.org/10.1017/S0376892911000282

Madzudzo, E. (1997). Communal Tenure, Motivational Dynamics and Sustainable Wildlife Management in Zimbabwe. Zambezia, 24, 147-158.

Mamimine, W., \& Mandiregerei, P. (2001). Traditional and Modern Institution of Governments in Community Based Natural Resources Management. Commons Southern Africa Occasional Paper Series No. 5. Harare: CASS.

Mashapa, C. (2018). Human Livelihoods and Sustainable Conservation: Herbivory and Anthropogenic Impacts on Woody Vegetation and Ecosystem Goods in Save Valley, Southeastern Zimbabwe. Ph.D. Thesis, Chinhoyi: Chinhoyi University of Technology.

Mashapa, C., Gandiwa, E., \& Muboko, N. (2019). Socio-Economic and Ecological Outcomes of Woodland Management in Mutema-Musikavanhu Communal Areas in Save Valley, Southeastern Lowveld of Zimbabwe. Journal of Animal and Plant Sciences, 29, 1075-1087.

McCullum, H. (2000). Biodiversity of Indigenous Forests and Woodlands in Southern 
Africa. Maseru and Harare: SADC/IUCN/SARDC.

McGregor, J. (1991). Woodland Resources: Ecology, Policy and Ideology: An Historical Case Study of Woodland Use in Shurugwi Communal Area, Zimbabwe. Loughborough: Loughborough University of Technology.

Moyo, S., O'Keefe, P., \& Sill, M. (1993). The Southern African Environment. Profiles of the SADC Countries, London: Earthscan Publications.

Muboko, N., Chigumira, T., Mashapa, C., Gandiwa, E., Chibememe, G., \& Mposhi, V. K. (2014). Impacts of Wood Poaching on Vegetation Structure and Composition in $\mathrm{Mu}$ kuvisi Woodland, Zimbabwe. Journal of Environmental Protection, 5, 156-163.

https://doi.org/10.4236/jep.2014.52019

Mugabe, J., \& Clark, N. (1998). Managing Biodiversity: National Systems for Conservation Innovation in Africa. Nairobi: African Centre for Technology Studies (ACTS).

Murphree, M. W. (1993). Communities as Resource Management Institutions. Gatekeeper Series No. 36, IIED.

Murphree, M. W. (2005). Congruent Objectives, Competing Interests, and Strategic Compromise: Concept and Process in the Evolution of Zimbabwe's CAMPFIRE, 1984-1996. In J. P. Brosius (Ed.), Communities and Conservation: Histories and Politics of Community-Based Natural Resource Management (pp. 105-147). Lanham, MD: AltaMira Press.

Mutepfa, F., Marongwe, E., Guveya, E., \& Lue Mbizvo, C. (1998). Enhancing Land Reforms in Southern Africa: Case Studies on Land Reform Strategies and Community-Based Natural Resources Management. Harare: ZERO-Regional Environment Organization.

Nduku, W. (1993). Wildlife Conservation in Africa. Harare: SARDC.

Nkonya, E., Pender, J., Kato, E., Mugarura, S., \& Muwonge, J. (2005). Who Knows, Who Cares? Determinants of Enactment, Awareness and Compliance with Community Natural Resources Management By-Laws in Uganda. CAPRI Working Paper 43. Washington DC: IFPRI.

Penny, R. (2009). Land Use, Land Cover and Earth Sciences Vol. 5: Desertification and Deforestation in Nigeria.

Reid, H. (2002). Contractual National Parks: Meeting Conservation and Development Objectives in South Africa and Australia. Ph.D. Thesis, Durrell Institute of Conservation and Ecology, University of Kent at Canterbury.

Reid, H., \& Turner S. (2004). The Richtersveld and Makuleke Contractual Parks in South Africa: Win-Win for Communities and Conservation? In C. Fabricius, \& E. Koch (Eds.), Rights, Resources and Rural Development: Community-Based Natural Resource Management in Southern Africa (pp. 223-234). London: Earthscan.

Shumba, E. M. (2001). Integration of Biodiversity in National Forestry Planning Programme. In International Workshop Integration of Biodiversity in National Forestry Planning Programme (pp. 1-16). Bogor: CIFOR Headquarters.

Sloan, S., \& Sayer, J. A. (2015). Forest Resources Assessment of 2015 Shows Positive Global Trends, But Forest Loss and Degradation Persist in Poor Tropical Countries. Forest Ecological Management, 352, 134-145. https://doi.org/10.1016/j.foreco.2015.06.013

Stuat, S. N., \& Adams, R. J. (1990). Biodiversity in Sub-Saharan Africa and Its Islands, Conservation Management and Sustainable Use. Gland: IUCN Species Survival Commission.

Thomas, C. (2004). Preliminary Report on the Smithsonian Institution Expedition to 
Gabon, April/May 2004 to Establish a 1-ha Forest Dynamics Plot Using CTFS Methodology (10 p.). Washington DC: Smithsonian Institution.

Tsai, Y. H., Stow, D. A., López-Carr, D., Weeks, J. R., Clarke, K. C., \& Mensah, F. (2019). Monitoring Forest Cover Change within Different Reserve Types in Southern Ghana. Environmental Monitoring and Assessment, 191, 1-15.

https://doi.org/10.1007/s10661-019-7450-z

WWF (2001). The Miombo Eco-Region (p. 22). Harare: WWF, Southern Africa Regional Programme Office.

ZimStats (Zimbabwe National Statistical Agency) (2013). Population Census, Census 2012: Zimbabwe Main Report. Harare: ZimStats. 